\title{
Chemiluminescence of human polymorphonuclear leucocytes after stimulation with whole cells and cell-wall components of Staphylococcus epidermidis
}

\author{
L. MARTÍNEZ-MARTÍNEZ* , C. P. TIMMERMAN, A. FLEER and J. VERHOEF
}

\begin{abstract}
Eijkman-Winkler Laboratory of Medical Microbiology, University of Utrecht, 3584 Utrecht, The Netherlands and * Department of Microbiology, School of Medicine, University of Seville, 41080 Seville, Spain
\end{abstract}

\begin{abstract}
Summary. The purpose of this study was to define cell-wall components of Staphylococcus epidermidis responsible for activation of human polymorphonuclear leucocytes (PMNL). Metabolic activation of PMNL was determined by chemiluminescence (CL). Purified peptidoglycan (PG) induced a concentration-dependent metabolic burst in PMNL. The minimal concentration needed for CL induction was $1 \mu \mathrm{g} / \mathrm{ml}$. Comparison between different S. epidermidis strains showed variation in the capacity to induce CL in PMNL. Purified PG induced a higher CL response in PMNL than its intact parent strain; this effect was found in all S. epidermidis strains. Lipoteichoic acid (LTA), PG stem peptide and muramyldipeptide (MDP) did not induce CL; teichoic acid induced a CL response only at very high concentrations. No differences in CL inducing capacity were found between PG, crude cell walls, and purified cell walls of $S$. epidermidis. Sonication of PG strongly diminished CLinducing capacity. PG treatment with mutanolysin immediately resulted in decreased CLinducing capacity. Treatment of PG with $S$. aureus lytic enzyme (SALE) $10 \mu \mathrm{g} / \mathrm{ml}$ for up to 15 min enhanced the CL response to PMNL; a similar increase in CL was induced by PG treated with SALE at $1 \mu \mathrm{g} / \mathrm{ml}$ for up to $120 \mathrm{~min}$. Beyond these times, a continuous decrease in PG-induced CL was observed. In conclusion, PG was found to be the major cell-wall component of S. epidermidis involved in CL induction. Moreover, a minimal fragment size or a specific tertiary structure of PG, or both, is required for metabolic activation of PMNL.
\end{abstract}

\section{Introduction}

Staphylococcus epidermidis, the most frequently isolated pathogen among the coagulase-negative staphylococci (CNS), has emerged as an important cause of nosocomial infection. Immunocompromised hosts, such as neonates and oncology patients, with indwelling prosthetic devices are especially susceptible to infection with CNS. ${ }^{1-3}$

The bacterial cell surface may be considered as a mosaic structure, allowing all major components to interact with external factors. ${ }^{4}$ In $S$. aureus infections, peptidoglycan (PG), teichoic acid (TA), lipoteichoic acid (LTA), protein $A$ and other cell-wall components were shown to play an important role in pathogenesis. PG, representing about $50 \%$ of the cell-wall dry weight of staphylococci, ${ }^{5}$ has also been suggested to play an important role in the host-parasite interaction in $S$. epidermidis infections. PG derived from different bacterial species (including gram-negative species) exhibits various biological effects on the immune system: inhibition of chemotaxis, phagocytosis and killing by polymorphonuclear leucocytes (PMNL),

Received 9 Sept. 1992; revised version accepted 4 Feb. 1993. induction of chemiluminescence (CL) in both PMNL and monocytes, ${ }^{6,7}$ and activation of complement via the alternative and classical pathways. ${ }^{8,9}$ TA, derived from $S$. aureus, has been shown to activate complement; ${ }^{9}$ however, the precise interaction of TA with PMNL is less clearly defined. Some studies have focused on staphylococcal LTA, which was found to promote adherence of both $S$. aureus and $S$. saprophyticus to epithelial cells ${ }^{10,11}$ and may induce $\mathrm{CL}$ and release of cytotoxic factors from macrophages. ${ }^{6}$

In this paper, we report the interaction of $S$. epidermidis and its cell-wall components with human PMNL by studying the induction of CL.

\section{Materials and methods}

\section{Bacterial strains}

Three S. epidermidis strains (291, 354, and 412) obtained from patients with catheter-related bacteraemia were used in this study. Strains were identified according to the scheme of Kloos and Schleifer ${ }^{12}$ by the API-Staph system (API System S.A., Montalieu Vercieu, France). Bacteria were subsequently ly- 
ophilised. Before each experiment the bacteria were cultured on blood agar.

\section{Preparation of cell-wall components}

Cell-wall components were prepared according to the method of Wilkinson et al. ${ }^{9}$ with minor modifications. Bacteria were grown in PYK medium (yeast extract $5 \mathrm{~g} / \mathrm{L}$, phytone peptone $5 \mathrm{~g} / \mathrm{L}, \mathrm{K}_{2} \mathrm{HPO}_{4} /$ $3 \mathrm{~g} / \mathrm{L}$, glucose $2 \mathrm{~g} / \mathrm{L}, \mathrm{pH} 7 \cdot 2-7 \cdot 4$ ) and incubated at $37^{\circ} \mathrm{C}$ for $2-4 \mathrm{~h}$. These log-phase bacteria were inoculated into fresh PYK medium and incubated at $37^{\circ} \mathrm{C}$ for $18 \mathrm{~h}$ with shaking. Bacteria were harvested by centrifugation $\left(5000 \mathrm{~g}, 10 \mathrm{~min}, 4^{\circ} \mathrm{C}\right)$ and washed three times with cold distilled water. Bacterial cells were disrupted with a cell homogeniser (BeadBeater Cell Disrupter; Biospec Products, Bartlesville, OK, USA) and $0 \cdot 1-\mathrm{mm}$ diameter glass beads; the cell homogeniser was operated for five cycles of $90 \mathrm{~s}$, with 90 -s intervals between each cycle. Afterwards the beads were allowed to settle, the supernate was recovered and the beads were washed three more times with distilled water. The pooled supernates were centrifuged $\left(1000 \mathrm{~g}, 5 \mathrm{~min}, 4^{\circ} \mathrm{C}\right)$ to remove any glass beads. The supernate was centrifuged at $13800 \mathrm{~g}$ for $10 \mathrm{~min}$ at $4^{\circ} \mathrm{C}$; the white top layer of the pellet containing bacterial cell walls was removed. The supernate of strain 354 was retained for isolation of lipoteichoic acid (LTA), as described later. Cell walls were resuspended in cold distilled water and washed. The pellet was resuspended in $200 \mathrm{ml}$ of distilled water and a gram-stained film was examined to confirm the virtual absence of intact staphylococcal cells. A 20-ml volume was separated, washed four times with distilled water, and lyophilised to obtain crude cell walls $(\mathrm{CCW})$. The remaining material was resuspended and incubated overnight with sodium dodecylsulphate (BDH Chemicals) 2\%. The material was washed twice with distilled water, then with $0.05 \mathrm{M} \mathrm{NaH}_{2} \mathrm{PO}_{4}$ $(\mathrm{pH} \mathrm{7.0)}$ and $0.05 \mathrm{M}$ Tris- $\mathrm{HCl}(\mathrm{pH} \mathrm{7.5)}$. Cell walls were resuspended in $200 \mathrm{ml}$ of $0.05 \mathrm{M}$ Tris- $\mathrm{HCl}$ containing $5 \mathrm{M} \mathrm{MgCl}_{2}$, DNAase (Boehringer Mannheim, Germany) $5 \mu \mathrm{g} / \mathrm{ml}$ and RNAase (Boehringer Mannheim) $5 \mu \mathrm{g} / \mathrm{ml}$ and stirred slowly at $37^{\circ} \mathrm{C}$ for $1 \mathrm{~h}$; trypsin (Sigma) $200 \mu \mathrm{g} / \mathrm{ml}$ was added and stirred for a further period of $4 \mathrm{~h}$. After centrifugation, the pellet was resuspended in $50 \mathrm{ml}$ of distilled water, mixed with $50 \mathrm{ml}$ of phenol (Merck) $80 \%$, and stirred vigorously at room temperature for $30 \mathrm{~min}$. After centrifugation, the purified cell walls (PCW) were collected carefully from the interface, resuspended in distilled water and washed five times with cold distilled water; $10 \mathrm{ml}$ of PCW were removed and lyophilised. The remaining PCW preparation was resuspended in trichloroacetic acid (TCA; Merck) $10 \%$ and incubated at $60^{\circ} \mathrm{C}$ for $90 \mathrm{~min}$ to remove teichoic acids (TA); the remaining PG was washed five times with cold distilled water and lyophilised.

TA was isolated by extracting PCW (from strain 354) with TCA $10 \%$ for $24 \mathrm{~h}$ at $4^{\circ} \mathrm{C}$. Cell walls were recovered by centrifugation and the supernate was retained. The extraction procedure was repeated twice. Pooled supernate were mixed with cold ethanol $95 \%$ $(1: 5 \mathrm{v}: \mathrm{v})$ and TA was precipitated overnight. TA was recovered by centrifugation $\left(5000 \mathrm{~g}, 4^{\circ} \mathrm{C}, 15 \mathrm{~min}\right)$, reconstituted in a minimal volume of TCA and reprecipitated with cold ethanol $95 \%$. TA was washed three times with acetone by centrifugation, dialysed against distilled water and lyophilised.

Isolation of LTA was performed according to the method of Wicken and Knox. ${ }^{13}$ After treatment of strain 354 with the cell homogeniser and removal of cell walls, the retained supernate was freeze-dried. The retained supernate was then reconstituted in water $5 \%$ $\mathrm{w} / \mathrm{v}$ and treated with phenol $90 \%$ at $4^{\circ} \mathrm{C}$ for $1 \mathrm{~h}$. The aqueous layer was removed and the phenol layer was washed with one volume of water. The pooled aqueous layers were dialysed three times against distilled water and the non-dialysable material was lyophilised; this material was stirred with chloroform-methanol (2:1, $\mathrm{v}: \mathrm{v})$ for $2 \mathrm{~h}$ at room temperature. After centrifugation $(12000 \mathrm{~g}, 20 \mathrm{~min})$ the chloroform-methanol was removed, the insoluble material was treated with DNAase and RNAase for $16 \mathrm{~h}$ at $37^{\circ} \mathrm{C}$ and the digest treated with phenol as described earlier. The aqueous fraction was dialysed against distilled water and LTA was prepared by freeze-drying, extracted once more with chloroform-methanol and finally dried ex vacuo.

\section{Sonication of peptidoglycan}

A suspension of PG $2 \mathrm{mg} / \mathrm{ml}$ in distilled water was sonicated with a tip sonicator (Sonifier ${ }^{\circledR}$ B-12; Branson Sonic Power Co., USA) on ice. Sonication was performed for three times, $10 \mathrm{~s}$ each, and for 10,30 and $60 \mathrm{~min}$. Sonication was used for no more than $15 \mathrm{~min}$, with 5-min intervals for cooling when necessary.

\section{Treatment of peptidoglycan with lytic enzymes}

Mutanolysin (Ml enzyme) and $S$. aureus lytic enzyme (SALE) (a gift from Dr S. Kotani, Japan) were used to break down PG. PG $(2 \mathrm{mg} / \mathrm{ml})$ was treated with $\mathrm{Ml} 10 \mu \mathrm{g} / \mathrm{ml}$ in $0.01 \mathrm{M}$ sodium acetate buffer, pH 5.5 , at $37^{\circ} \mathrm{C}$ for 5,15 or $30 \mathrm{~min}, 1,2$ or $4 \mathrm{~h}$, or with SALE, 1 or $10 \mu \mathrm{g} / \mathrm{ml}$ in phosphate buffered saline (PBS), pH 8.0, for 5,15 or $30 \mathrm{~min}, 1,2,4,7,24$ or $48 \mathrm{~h}$. At fixed times, 1-ml samples were taken from the suspensions, which were then heated at $100^{\circ} \mathrm{C}$ for $10 \mathrm{~min}$ to inactivate the enzyme after addition of $1 \mathrm{ml}$ of buffer (final PG concentration $1 \mathrm{mg} / \mathrm{ml}$ ). Breakdown of PG was monitored by measuring the absorbance at $660 \mathrm{~nm}\left(\mathrm{~A}_{660}\right)$ with a spectrophotometer (Coleman 575 Spectrophotometer, Perkin Elmer, USA).

\section{Human polymorphonuclear leucocytes}

PMNL were isolated from heparinised venous blood from healthy adult donors by dextran T70 (Pharmacia 
Fine Chemicals, Uppsala, Sweden) sedimentation of erythrocytes, differential density centrifugation on Ficoll-Paque (Pharmacia) and lysis of contaminating erythrocytes by hypotonic shock. PMNL were adjusted to a final concentration of $1 \times 10^{7}$ cells $/ \mathrm{ml}$ in Hanks's Balanced Salts Solution containing gelatin $0.1 \%$ (gel-HBSS) with a Coulter Counter (Coulter Electronics, Harpenden, Herts). Purity of PMNL exceeded $97 \%$ (Wright's stain) and viability exceeded $97 \%$ (trypan blue exclusion). For some experiments the same procedure was used to isolate PMNL from a patient with chronic granulomatous disease.

\section{$P M N L$ priming with $P G$ derivatives}

To study the priming effect of PG components, PMNL $\left(10^{7}\right.$ cells $\left./ \mathrm{ml}, 1 \mathrm{ml}\right)$ were incubated with muramyldipeptide (MDP; Sigma), PG stem peptide (L-alanyl-D-isoglutaminyl-L-lysyl-D-alanyl-D-alanine acetate; Sigma), and PG of S. epidermidis strain 354 (at concentrations of 10 and $100 \mu \mathrm{g} / \mathrm{ml}$ ) at different times $(5,30,60$ and $240 \mathrm{~min})$. PMNL and PG derivatives were incubated at $37^{\circ} \mathrm{C}$ in a water bath. PMNL were washed twice with gel-HBSS and reconstituted in $1 \mathrm{ml}$ of the same buffer. Cells were then exposed to phorbol 12-myristate 13-acetate (PMA; Sigma) $50 \mathrm{ng} / \mathrm{ml}$. The priming effect of PG on PMNL was determined by measurement of PMNL CL. Unprimed PMNL (from the same donor), incubated and stimulated under the same conditions, were used as a control.

\section{CL assay}

Luminol-enhanced CL of PMNL was measured over a period to assess the metabolic burst in the cells. ${ }^{14}$ Gel-HBSS $(150 \mu \mathrm{l})$ containing the staphylococcal stimulus was mixed with $40 \mu \mathrm{l}$ of the same buffer containing luminol $\left(3.75 \times 10^{-6} \mathrm{M}\right)$ and $150 \mu \mathrm{l}$ of PMNL suspensions $\left(10^{7}\right.$ cells $\left./ \mathrm{ml}\right)$. The staphylococcal cell-wall components to be tested were used at the following concentrations: PG $0 \cdot 1-1000 \mu \mathrm{g} / \mathrm{ml}$, TA and LTA $25-1000 \mu \mathrm{g} / \mathrm{ml}$, and $100 \mu \mathrm{g} / \mathrm{ml}$ for all other cell-wall derivatives, including $\mathrm{CCW}, \mathrm{PCW}, \mathrm{MDP}$ and PG stem peptide. Whole bacterial cells were incubated with PMNL at a concentration of $10^{9} \mathrm{cfu} / \mathrm{ml}$. In some experiments opsonised bacteria and PG were also studied. PMA $50 \mathrm{ng} / \mathrm{ml}$ and a fixed amount of PG $(100 \mu \mathrm{g} / \mathrm{ml})$ were used as positive controls, and gelHBSS $150 \mu \mathrm{l}$ was used as a negative control. Light emission was measured in duplicate at 2-min intervals for at least $30 \mathrm{~min}$ in a luminometer (Packard Instruments, Belgium).

\section{Opsonisation procedures}

Human pooled serum (HPS) obtained from 50 healthy adult donors was used as a source of opsonins. Bacteria or PG were opsonised by incubation with shaking for $30 \mathrm{~min}$ at $37^{\circ} \mathrm{C}$ in different concentrations of HPS diluted in gel-HBSS. The serum was removed by centrifugation, and the opsonised bacteria or PG were resuspended in gel-HBSS and kept at $4^{\circ} \mathrm{C}$ until use. For some experiments complement was inactivated by heating $\mathrm{HPS}$ for $30 \mathrm{~min}$ at $56^{\circ} \mathrm{C}$.

\section{Statistical analysis}

In most experiments the peak values of PMNL CL were compared; to correct for differences in the $\mathrm{CL}$ activity of PMNL from different donors, the results were expressed as a percentage of the CL induced by a standard amount of PG, $100 \%$ being considered the peak of CL induced by PG $100 \mu \mathrm{g} / \mathrm{ml}$. All assays were performed on at least three different days, except in the comparison of normal PMNL and PMNL derived from a patient with chronic granulomatous disease. Each test was done in duplicate and only values obtained with PMNL from the same donor were compared. Results were compared by Student's $t$ test; differences were considered significant if $\mathrm{p}<0.05$.

\section{Results}

$\mathrm{CL}$ induced in PMNL by unopsonised $\mathrm{PG}$ $100 \mu \mathrm{g} / \mathrm{ml}$ and intact $S$. epidermidis strains $10^{9} \mathrm{cfu} / \mathrm{ml}$ is shown in fig. 1. Stimulation of PMNL with PG resulted in a peak value of $C L$ after $15 \mathrm{~min}$, whereas intact bacterial cells induced a peak value after 35-45 min. CL peaks after stimulation of PMNL with PG were higher than the peak after stimulation with whole bacterial cells of the homologous strain. Quantitative differences were found with PG from different S. epidermidis strains: the peak CL induced by PG of strain 412 was consistently higher than that induced by strain 291 with a maximal ratio of $2 \cdot 5$.

Variations in peak $C L$ were also found with different donor PMNL, although the same pattern was observed consistently (data not shown): the highest peak of CL was obtained with strain 412 , the lowest with strain 291. To correct for these variations, an internal control (PG 354, $100 \mu \mathrm{g} / \mathrm{ml}$ ) was used to compare results from separate experiments performed on different days.

The specific activity of PG to induce the metabolic burst in human PMNL was assessed by comparing the response of PMNL from normal donors and PMNL from a patient with chronic granulomatous disease. The response of the latter was not different from a negative control (gel-HBSS-stimulated PMNL), in contrast to normal PMNL.

The effect of different cell-wall components and intact $S$. epidermidis strains on CL of human PMNL is summarised in table I. Peaks of CL, expressed as the percentage of the peak induced by the homologous PG, were not statistically different ( $p>0.05)$ for PG, $\mathrm{CCW}$ and $\mathrm{PCW}$, when the same concentrations $(100 \mu \mathrm{g} / \mathrm{ml})$ were used. Significant differences $(p<0.01)$ were found when PG and the homologous viable strains were compared. Both TA and LTA 


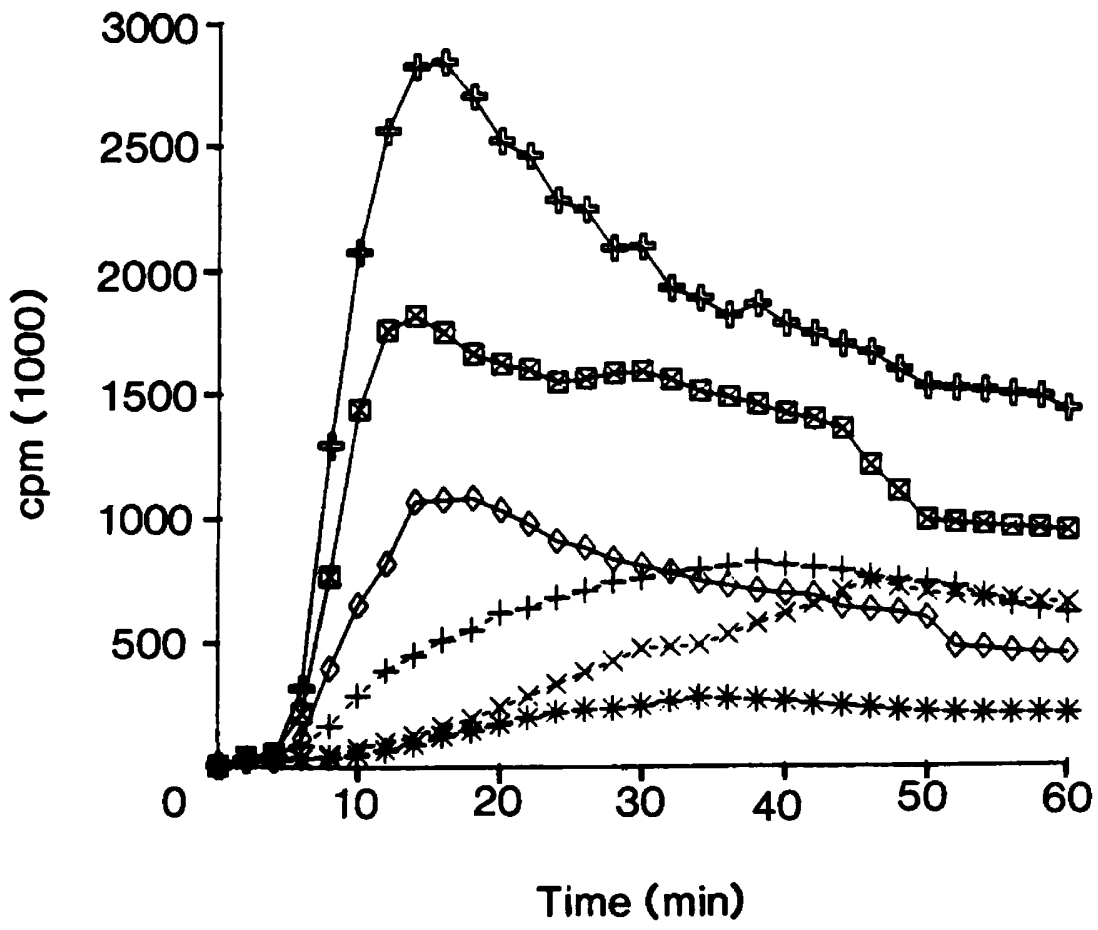

Fig. 1. Kinetics of human PMNL CL induced by PG $100 \mu \mathrm{g} / \mathrm{ml}(+, 412 ; \bigotimes, 354 ; \diamond, 291)$ and three intact $S$. epidermidis strains $\left(10^{9} \mathrm{cfu} / \mathrm{ml}\right)$ $(+, 412 ; \times, 354 ; \star, 291)$.

Table I. Peaks of CL of human PMNL induced by $S$. epidermidis $\left(10^{9} \mathrm{cfu} / \mathrm{ml}\right)$, or cell-wall components $(100 \mu \mathrm{g} / \mathrm{ml})$

\begin{tabular}{|c|c|c|c|c|c|c|c|}
\hline \multirow[b]{2}{*}{ Strain } & \multicolumn{7}{|c|}{ Mean (SD) peak $C^{*}$} \\
\hline & PG & $\mathrm{CCW}$ & PCW & TA & LTA & Whole cells & $\begin{array}{l}\text { Negative } \\
\text { control }\end{array}$ \\
\hline 354 & 100 & $106 \cdot 7(5 \cdot 6)$ & $101 \cdot 7(10 \cdot 7)$ & $2 \cdot 4(0 \cdot 3)$ & $2 \cdot 1(0 \cdot 8)$ & $52.0(15 \cdot 7)$ & $0.7(1 \cdot 1)$ \\
\hline 291 & 100 & $109 \cdot 8(10 \cdot 7)$ & $97 \cdot 4(6.4)$ & ND & ND & $73.4(6.9)$ & $0.9(0.9)$ \\
\hline 412 & 100 & $89.9(12.4)$ & $95 \cdot 3(8.6)$ & ND & ND & $15 \cdot 0(6 \cdot 7)$ & $0.7(1.0)$ \\
\hline
\end{tabular}

PG, peptidoglycan; CCW, crude cell wall; PCW, purified cell wall; TA, teichoic acid; LTA, lipoteichoic acid; ND, not determined. ${ }^{*} \mathrm{CL}$ expressed as percentage of response to PG; mean of three independent assays.

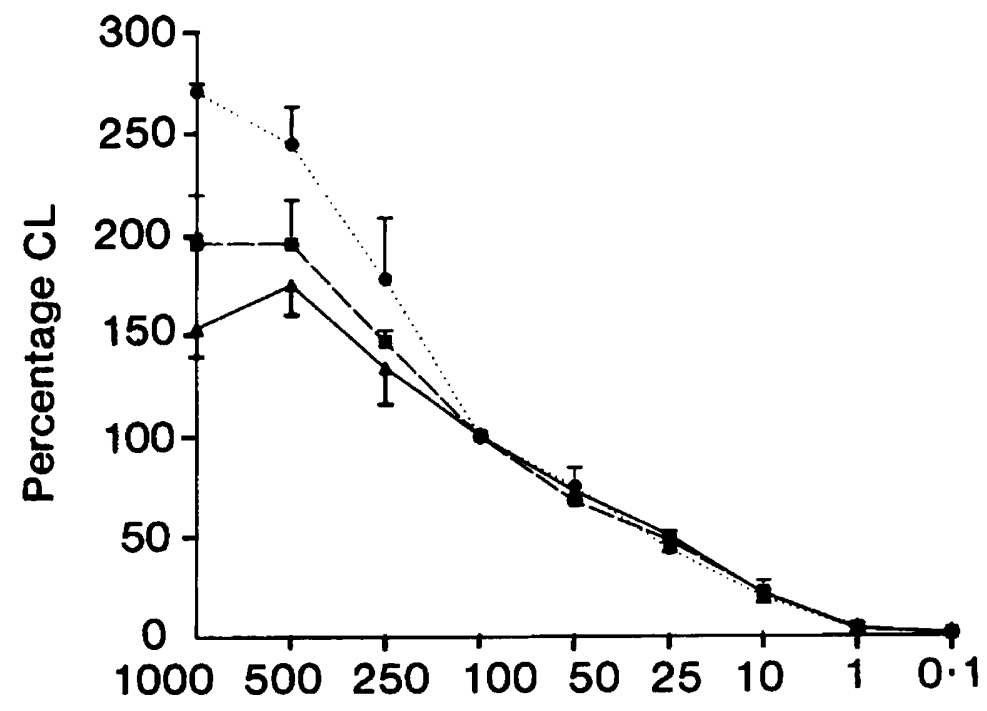

\section{Concentration of peptidoglycan $(\mu \mathrm{g} / \mathrm{ml})$}

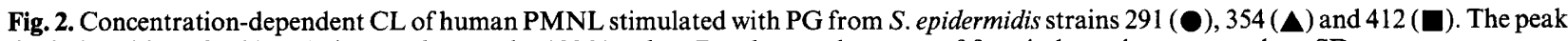
$\mathrm{CL}$ induced by PG $100 \mu \mathrm{g} / \mathrm{ml}$ was taken as the $100 \%$ value. Results are the mean of four independent assays; bar, SD. 


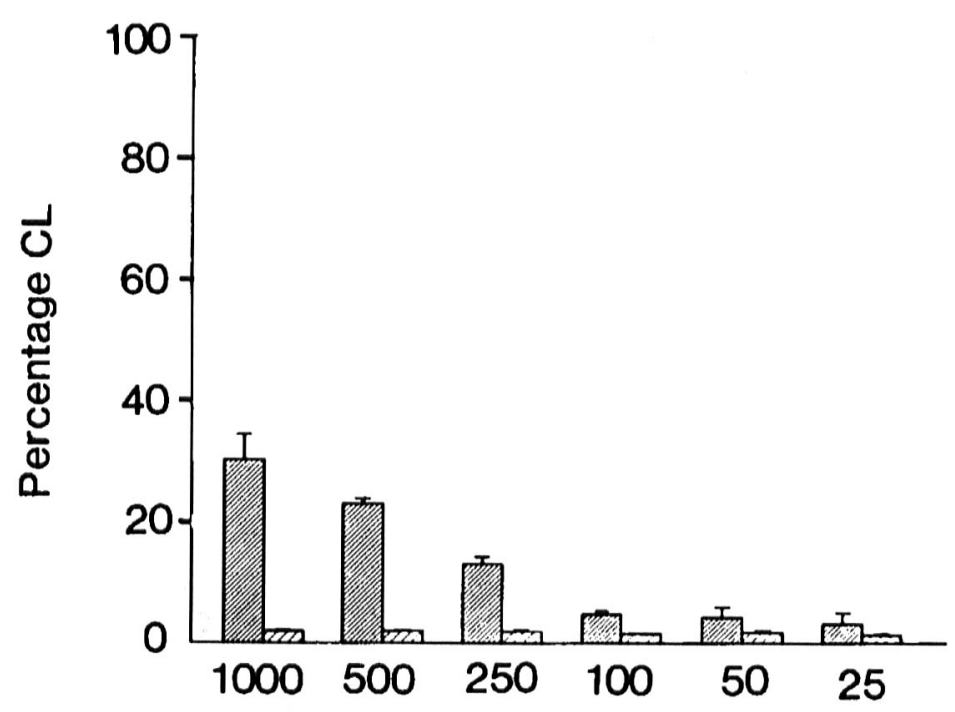

\section{Concentration $(\mu \mathrm{g} / \mathrm{ml})$ of TA or LTA}

Fig. 3. Capacity of TA ( was taken as the $100 \%$ value. Results are the mean of three independent assays; bar, SD.

induced a significantly $(\mathrm{p}<0.001)$ lower peak than PG. Interestingly the peak of CL after stimulation with TA was significantly higher $(p<0.05)$ than a negative control (gel-HBSS) in contrast to LTA stimulation.

Increasing amounts of $\mathrm{PG}$ of all three strains elicited a dose-related CL response in PMNL (fig. 2). The values induced by $500 \mu \mathrm{g} / \mathrm{ml}$ were not significantly different $(\mathrm{p}>0.05$ ) from those induced by $1000 \mu \mathrm{g} / \mathrm{ml}$. With all three $S$. epidermidis strains, a significant $\mathrm{CL}$ response was still induced at PG concentrations as low as $1 \mu \mathrm{g} / \mathrm{ml}$, compared to a negative control-PG 354 $(\mathrm{p}<0.01)$, PG $291(\mathrm{p}<0.01)$ and PG $412(\mathrm{p}<0.05)$.

Results obtained with increasing concentrations of TA and LTA derived from S. epidermidis strain 354 are shown in fig. 3. LTA at concentrations as high as $1000 \mu \mathrm{g} / \mathrm{ml}$ did not induce $\mathrm{CL}$, whereas TA induced a dose-related CL response in PMNL. Peak CL induced by $100 \mu \mathrm{g} / \mathrm{ml}$ (but not by $50 \mu \mathrm{g} / \mathrm{ml}$ ) were still significantly higher $(\mathrm{p}<0.05)$ than the negative control; as previously shown the response was lower ( $p<0.001)$ than $C L$ induced by the same amount of PG. TA at $1000 \mu \mathrm{g} / \mathrm{ml}$ induced a lower response (p $<0.001)$ than PG at $100 \mu \mathrm{g} / \mathrm{ml}$.

The effect of sonication of PG on CL induction is presented in fig. 4. Sonication for three cycles of $10 \mathrm{~s}$ resulted in a significant decrease in the peak value of CL, compared with non-sonicated PG $(\mathrm{p}<0.01$ for PG 354 and PG 412, $p<0.001$ for PG 291). Prolonged sonication resulted in even lower peaks of $C L$; sonication beyond a period of $10 \mathrm{~min}$ for PG 291 and 30 min for PG 412 resulted in a response which was not statistically different from a negative control; however, PG 354 still induced a higher response than the negative control when sonicated for 30 or $60 \mathrm{~min}$.

$A_{660}$ values of PG 354 after treatment with SALE and $\mathrm{Ml}$ enzyme are presented in fig. 5a. Ml treatment resulted in a rapid decrease of absorbance; after $30 \mathrm{~min}$

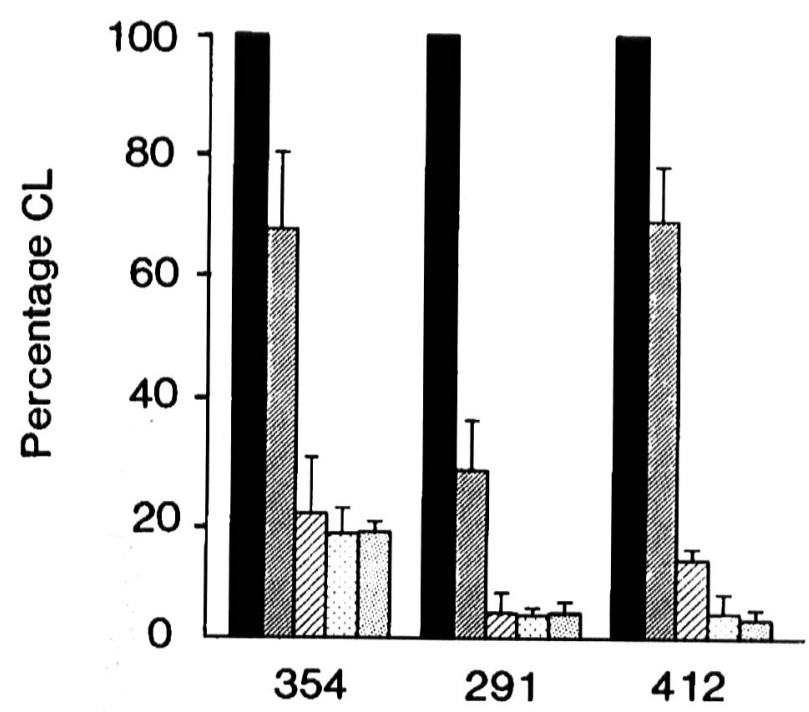

Strain no.

Fig. 4. Effect of sonication of PG on the CL of human PMNL. All PG samples were used at the same concentration $(100 \mu \mathrm{g} / \mathrm{ml})$. Results are the mean of three independent assays; bar, SD. Native $\mathrm{PG}, \square$; PG sonicated for $3 \times 10 \mathrm{~s}$, 即; $10 \mathrm{~min}, \square ; 30 \mathrm{~min}$, $\mathrm{O}$; $60 \mathrm{~min}$, 图

most of the material was degraded $\left(A_{660} 0 \cdot 071\right)$. In contrast, treatment of PG with SALE $10 \mu \mathrm{g} / \mathrm{ml}$ induced an initial increase in absorbance, which reached a peak between 30 and $60 \mathrm{~min}$; treatment beyond this time resulted in a continuous decrease, until the baseline $\left(A_{660} 0.010\right)$ was reached at $24 \mathrm{~h}$. A delay in degradation was found when a lower concentration $(1 \mu \mathrm{g} / \mathrm{ml})$ of the enzyme was used; a peak in absorbance appeared between 2 and $4 \mathrm{~h}$.

The materials obtained after enzymatic degradation were used in the CL assay; peaks of CL were closely related to the $A_{660}$ of the corresponding material (fig. $5 b$ ), but maximal values appeared earlier when considering peaks of CL. Treatment of PG 354 with Ml 

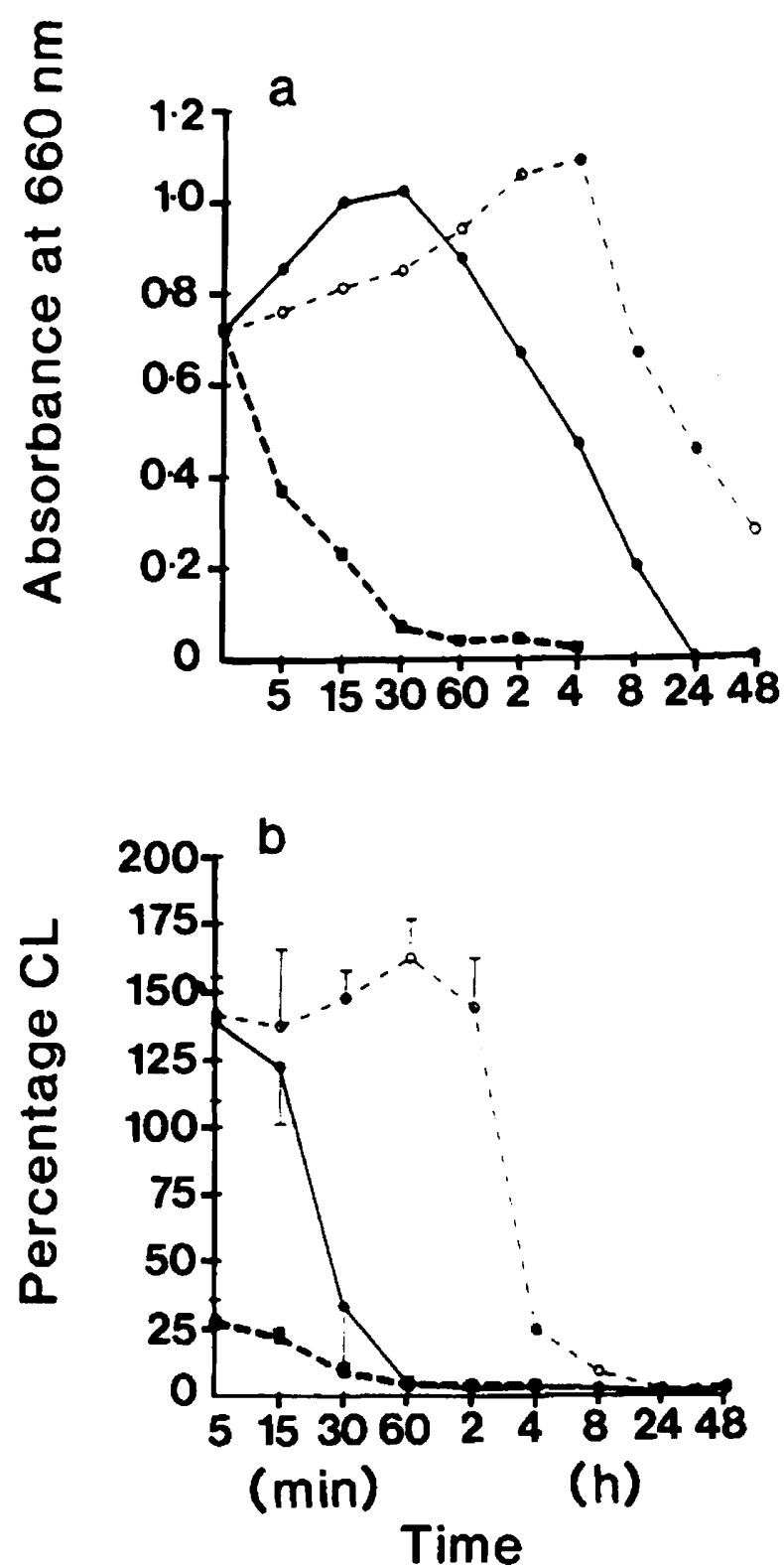

Fig. 5. a, Degradation of PG from S. epidermidis 354 with mutanolysin (Ml, $10 \mu \mathrm{g} / \mathrm{ml}, \boldsymbol{\square})$ and with $S$. aureus lytic enzyme (SALE, $10 \mu \mathrm{g} / \mathrm{ml}, 0$, or $1 \mu \mathrm{g} / \mathrm{ml}, \mathrm{O})$. b, CL of PMNL induced by enzyme (M1 and SALE)-treated PG $100 \mu \mathrm{g} / \mathrm{ml}$. The peak CL induced by untreated PG $100 \mu \mathrm{g} / \mathrm{ml}$ was taken as the $100 \%$ value. Results are the mean of three independent assays; bar, SD.

for only $5 \mathrm{~min}$ induced a quick reduction in $\mathrm{CL}$ response, with a continuous decrease thereafter. After $60 \mathrm{~min}$ the values obtained (4.1 SD 2.9) were not statistically different $(p>0.05)$ from a negative control
(gel-HBSS containing Ml) (3.3 SD 0.8). Treatment of PG 354 with SALE $10 \mu \mathrm{g} / \mathrm{ml}$ induced maximal peaks of CL at $5 \mathrm{~min}(135 \cdot 1 \mathrm{SD} 29 \cdot 3)$; peaks were still higher than in controls at $15 \mathrm{~min}(122 \mathrm{SD} 21.5)$, but at $30 \mathrm{~min}$ a marked decrease was observed (33.1 SD 21.1) and after $60 \mathrm{~min}$ the final material induced a similar $(p>0.05)$ response to the negative control. When SALE was used at $1 \mu \mathrm{g} / \mathrm{ml}$, maximal peaks induced by SALE-treated PG appeared at $60 \mathrm{~min}$ (162.5 SD 13.9); PG treated for 5-120 min induced peaks statistically $(p<0.001)$ higher than untreated PG; beyond this time, again, a decrease was noted and at $24 \mathrm{~h}$ the peak was not statistically different from the negative control $(\mathrm{p}>0.05)$.

Both MDP and PG stem peptide failed to induce significant $\mathrm{CL}$ in human PMNL, even at concentrations of $100 \mu \mathrm{g} / \mathrm{ml}: 1 \cdot 1 \mathrm{SD} 3.3$ (MDP) and 1.4 SD 0.6 (stem peptide) versus 100.0 SD 0 (positive control) and $1 \cdot 1$ SD $0 \cdot 2$ (negative control). Both materials and native PG also failed to induce a priming effect on human PMNL; when these materials were incubated with PMNL at different times ( $5 \min -4 \mathrm{~h}$ ), no differences were observed with control PMNL after subsequent stimulation with PMA.

Peaks of CL induced by both opsonised and unopsonised S. epidermidis strain 354 and PG are presented in table II. As previously stated (fig. 1), unopsonised PG induced higher CL peaks than the whole cells from the homologous strain; these differences persisted when S. epidermidis strain 354 was opsonised with HPS 1, 5 and $10 \%$, respectively. Also, at lower concentrations of PG $(10$ and $30 \mu \mathrm{g} / \mathrm{ml})$ opsonisation with fresh HPS significantly enhanced CL. PG opsonised with $0 \cdot 1,1,2 \cdot 5,5$ and $10 \%$ of heated serum, showed (in at least three independent

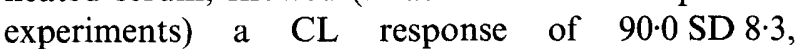
106.6 SD 9.2, 177.6 SD 12.5, 415.8 SD 23.2, $527 \cdot 6$ SD $25.6 \%$ respectively, when compared to unopsonised PG $354(100 \mu \mathrm{g} / \mathrm{ml})$. Thus, heated HPS when used in concentrations of $\geqslant 2.5 \%$ clearly enhanced CL induction by PG.

\section{Discussion}

This study has shown the capacity of different cellwall components of $S$. epidermidis strains to induce a

Table II. Peaks of CL of human PMNL after stimulation with intact $S$. epidermidis strain 354 or PG, both unopsonised and opsonised with human pooled serum

\begin{tabular}{c|cccc}
\hline \multirow{2}{*}{ Target } & \multicolumn{4}{|c}{ Mean (SD) peak CL* with } \\
\cline { 2 - 5 } & no serum & $1 \%$ serum & $5 \%$ serum & $10 \%$ serum \\
\hline $\begin{array}{c}\text { Peptidoglycan } \\
(100 \mu \mathrm{g} / \mathrm{ml})\end{array}$ & 100 & $284 \cdot 7(22 \cdot 4)$ & $578 \cdot 3(32 \cdot 4)$ & $519 \cdot 2(28 \cdot 7)$ \\
$\begin{array}{c}\text { S. epidermidis } \\
\left(10^{9} \mathrm{cfu} / \mathrm{ml}\right)\end{array}$ & $52 \cdot 0(15 \cdot 7)$ & $76 \cdot 3(14 \cdot 9)$ & $206 \cdot 6(18 \cdot 8)$ & $255 \cdot 3(26 \cdot 9)$ \\
\hline
\end{tabular}

${ }^{*} \mathrm{CL}$ expressed as percentage of $\mathrm{CL}$ obtained with homologous unopsonised $\mathrm{PG}$; mean of three independent assays. 
metabolic burst in human PMNL in the absence of opsonins. When used at the same concentration, PG, PCW and CCW induced a similar CL response. However, LTA did not induce CL, and the response induced by TA was minimal. Other authors ${ }^{6}$ have found that LTA induces CL and the production of cytotoxic factors in monocytes but not in PMNL. Of the major cell-wall components of $S$. epidermidis (PG, TA and proteins), only PG and TA are present in PCW. PG represents $>50 \%$ of the cell-wall dry weight and is closely associated with other cell-wall components (TA or proteins or both).

Our data indicate that PG is possibly the crucial component in the induction of an oxidative burst in human PMNL. Purified PG from several microorganisms has been shown to be responsible for a great variety of physiological activities: it adversely affects PMNL chemotaxis and phagocytosis, ${ }^{15}$ induces production of endogenous pyrogen, ${ }^{16}$ and causes leukopenia and thrombocytopenia during bacteraemia. ${ }^{17}$ Our data specifically refer to $S$. epidermidis $\mathrm{PG}$, but together these findings suggest that the proinflammatory activity of the macromolecule is not species-restricted, in agreement with the similar basic primary structure in different micro-organisms. ${ }^{18}$

In the three strains studied, unopsonised PG induced a higher and earlier CL response in PMNL than the intact bacteria. Bacterial cell walls should not be considered a rigid concentric multilayered structure, but rather a mosaic in which its different components are exposed to the environment, enabling $P G$, within the intact bacterial cell, to interact with cells or other environmental factors. The possible role of certain PG components in the process of lectinophagocytosis ${ }^{19}$ by PMNL may explain the induction of CL by intact bacteria in the absence of opsonins. Alternatively, surface-associated proteins, extracellular slime substance or other components may be of importance in this process. Further experiments must be performed to elucidate these aspects.

Our data show that induction of CL in PMNL by PG is dose-dependent. A significant response is still found with concentrations of PG as low as $1 \mu \mathrm{g} / \mathrm{ml}$, while a maximal response is found at $500-1000 \mu \mathrm{g} / \mathrm{ml}$. Although the clinical relevance of the last figures may be doubtful, it seems justifiable to attribute physiopathological importance to $P G$ concentrations in lower ranges. TA (but not LTA) induced a doserelated response; however, peaks of CL induced by TA were much lower than after PG stimulation, when the same concentration of both materials was compared. This result supports a more important role for PG than for TA in the induction of the metabolic burst in human PMNL.

The size or tertiary structure, or both, of PG seem to be critical for PMNL activation. Sonication of PG severely affected its capacity to activate PMNL: sonication for only three cycles of $10 \mathrm{~s}$ resulted in a marked decrease in the peak values of CL; sonication beyond this period resulted in disappearance of the $\mathrm{CL}$ inducing capacity of PG of two of the three strains tested, and was minimal in the third one.

To perform a more detailed study on the size of PG fragments on PMNL activation, PG was enzymically treated. Two different enzymes were used-a glycosidase, Ml enzyme, and an endopeptidase (SALE) ${ }^{20,21} \mathrm{Ml}$ induces rapid solubilisation of the $\mathrm{PG}$ by cleaving the linkage between $\mathrm{N}$-acetylmuramic acid and $\mathrm{N}$-acetylglucosamine, independently of the presence of O-acetyl groups. ${ }^{21} \mathrm{PG}$ fragments after $\mathrm{Ml}$ degradation are characterised by a polysaccharide chain with decreasing number of residues as the treatment progresses, and their ability to induce a metabolic burst in human PMNL practically disappeared after treatment for $5 \mathrm{~min}$. SALE induces PG solubilisation after splitting the inter-peptide bridge in PG. ${ }^{20}$ Two different concentrations of this enzyme induced a similar pattern of PG degradation: initially there was an increase in $\mathbf{A}_{600}$ (appearing later with lower concentrations of the enzyme), followed by a continuous decrease, as observed with Ml enzyme. Materials treated at different times with SALE also varied in their capacity to induce CL in PMNL, but with both concentrations, 1 and $10 \mu \mathrm{g} / \mathrm{ml}$, a higher absorbance was partially related to a higher peak of $C L$, even superior to that of the untreated material. Again with both concentrations of SALE, a sharp drop in the capacity of CL induction was observed, concurrent with a decrease in absorbance similar to that observed on treatment with Ml enzyme, suggesting that this PG capacity is closely related to a minimal fragment size or a specific tertiary structure, or both, in agreement with the results previously obtained with sonication. Enzymically treated PG induced CL only when insoluble material was present; as soon as PG was solubilised, even partially $(5 \mathrm{~min}$ with Ml, $30 \mathrm{~min}$ with SALE $10 \mu \mathrm{g} / \mathrm{ml}, 8 \mathrm{~h}$ with SALE $1 \mu \mathrm{g} / \mathrm{ml}$ ) its capacity to stimulate PMNL was totally abolished. The primary structure of the PG macromolecule in $S$. epidermidis is well known, in contrast to the tertiary structure which is still unknown, which makes it difficult to relate $\mathrm{CL}$ to a particular threedimensional configuration of the $P G$. The rapid activity of $\mathrm{Ml}$ in obliterating $\mathrm{CL}$-inducing activity could be explained by a higher ability to solubilise PG or by the specific breakdown of the amino-sugar linkages, if the polyglycan chain is the basic chemical structure involved in PMNL activation. Further experiments, including mol. wt determination of the different fragments and the use of an amidase, splitting the $\mathrm{N}$-acetylmuramic acid and L-alanine linkage, will be critical to clarify these possibilities.

Our data also indicate that MDP and PG stem peptide, both soluble materials, are unable to induce a metabolic burst in human PMNL. We also found that MDP had no priming effect, in agreement with Kaku et al. who reported similar findings with guinea-pig PMNL, ${ }^{22}$ but in disagreement with Jupin et al., who showed that MDP primed human PMNL to a second stimulus. ${ }^{23}$ As these authors used superoxide pro- 
duction with the nitroblue tetrazolium reduction test as a marker for PMNL activation, differences in methodologies may explain the discrepancies. PG itself, being able to stimulate PMNL as previously shown, lacks the capacity to prime these cells, in contrast to the properties of bacterial lipopolysaccharide. ${ }^{24,25}$

In conclusion, the present study showed PG to be the most important cell-wall determinant of $S$.

\section{References}

1. Fleer A, Verhoef J. New aspects of staphylococcal infections: emergence of coagulase-negative staphylococci as pathogens. Antonie van Leeuwenhoek 1984; 50: 729-744.

2. Anon. Coagulase-negative staphylococci. Lancet 1981; 1: 139-140.

3. Ponce de Leon S, Wenzel RP. Hospital-acquired bloodstream infections with Staphylococcus epidermidis. Review of 100 cases. Am J Med 1984; 77: 639-644.

4. Wagner M, Ryc M, Wagner B. Electronmicroscopic localization of peptidoglycan in the cell wall of Streptococcus pyogenes by means of labelled antibodies and lysozyme. In: Seidl $\mathrm{PH}$, Schleifer $\mathrm{KH}$ (eds) Biological properties of peptidoglycan. Berlin, W de Gruyter. 1986: 129-134.

5. Peterson PK, Wilkinson BJ, Kim Y et al. The key role of peptidoglycan in the opsonization of Staphylococcus aureus. J Clin Invest 1978; 61: 597-609.

6. Dziarski R. Effects of peptidoglycan on the cellular components of the immune system. In: Seidel PH, Schleifer KH (eds) Biological properties of peptidoglycan. Berlin, W de Gruyter. 1986: 229-247.

7. Musher DM, Verbrugh HA, Verhoef J. Suppression of phagocytosis and chemotaxis by cell wall components of Staphylococcus aureus. J Immunol 1981; 127: 84-88.

8. Verbrugh HA, van Dijk WC, Peters R, van der Tol ME, Verhoef J. The role of Staphylococcus aureus cell-wall peptidoglycan, teichoic acid and protein $\mathrm{A}$ in the process of complement activation and opsonization. Immunology $1979 ; 37: 615-621$

9. Wilkinson BJ, Kim Y, Peterson PK, Quie PG, Michael AF. Activation of the complement by cell surface components of Staphylococcus aureus. Infect Immun 1978; 20: 388-392.

10. Aly R, Shinefield HR, Litz C, Maibach HI. Role of teichoic acid in the binding of Staphylococcus aureus to nasal epithelial cells. J Infect Dis 1980; 141: 463-465.

11. Teti G, Chiofalo MS, Tomasello F, Fava C, Mastroeni P. Mediation of Staphylococcus saprophyticus adherence to uroepithelial cells by lipoteichoic acid. Infect Immun 1987; 55: 839-842.

12. Kloos WE, Schleifer KH. Simplified scheme for routine identification of human staphylococcal species. $J$ Clin Microbiol 1975; 1: 82-88.

13. Wicken AJ, Knox KW. Studies on the group F antigen of Lactobacilli: isolation of a teichoic acid-lipid complex from Lactobacillus fermenti NCTC 6991. J Gen Microbiol 1970; 60: 293-301. epidermidis strains in inducing PMNL CL, which was found to occur in a dose-dependent manner. Purified $P G$ induced an earlier and higher $C L$ response in PMNL than intact bacterial cells. Furthermore, it was found that a possible critical size or tertiary structure of the PG molecule was both responsible and required for the activation of PMNL. Our experiments also showed that opsonisation of PG by both complement and antibody considerably enhanced CL.

14. Stevens P, Winston DJ, Van Dyke K. In vitro evaluation of opsonic and cellular granulocyte function by luminoldependent chemiluminescence: utility in patients with severe neutropenia and cellular deficiency states. Infect Immun 1978; 22: 41-51.

15. Weksler BB, Hill MJ. Inhibition of leukocyte migration by a staphylococcal factor. J Bacteriol 1969; 98: 1030-1035.

16. Oken MM, Peterson PK, Wilkinson BJ. Endogenous pyrogen production by human blood monocytes stimulated by staphylococcal cell wall components. Infect Immun 1981; 31 : 208-213.

17. Spika JS, Peterson PK, Wilkinson BJ et al. Role of peptidoglycan from Staphylococcus aureus in leukopenia, thrombocytopenia, and complement activation associated with bacteremia. $J$ Infect Dis 1982; 146: 227-234.

18. Schleifer KH, Kandler O. Peptidoglycan types of bacterial cell walls and their taxonomic implications. Bacteriol Rev 1972; 36: 407-477.

19. Ofek I, Sharon N. Lectinophagocytosis: a molecular mechanism of the recognition between cell surface sugars and lectins in the phagocytosis of bacteria. Infect Immun 1988; 56: $539-547$.

20. Kawata S, Takemura T, Yokogawa K, Kotani S. Isolation of bacteriolytic endopeptidase from a strain of Cytophaga and its application to preparation of hydrosoluble polysaccharide peptide from Staphylococcus epidermidis peptidoglycan. Agric Biol Chem 1984; 48: 2253-2263.

21. Kawata S, Takamura T, Yokogawa K. Characterization of two $\mathrm{N}$-acetylmuramidases from Streptomyces globisporum 1829. Agric Biol Chem 1983; 47: 1501-1508.

22. Kaku M, Yagawa K, Nagao S, Tanaka A. Enhanced superoxide anion release from phagocytes by muramyl dipeptide or lipopolysaccharide. Infect Immun 1983; 39: 559-564.

23. Jupin C, Parant M, Chedid L, Damais C. Enhanced oxidative burst without interleukin 1 production by normal human polymorphonuclear leukocytes primed with muramyl dipeptides. Inflammation 1987; 11: 153-161.

24. Forehand JR, Pabst MJ, Phillips WA, Johnston RB. Lipopolysaccharide priming of human neutrophils for an enhanced respiratory burst. Role of intracellular free calcium. J Clin Invest 1989; 83: 74-83.

25. Guthrie LA, McPhail LC, Henson PM, Johnston RB. Priming of neutrophils for enhanced release of oxygen metabolites by bacterial lipopolysaccharide. Evidence for increased activity of the superoxide-producing enzyme. $J$ Exp Med $1984 ; 160$ : 1656-1671. 